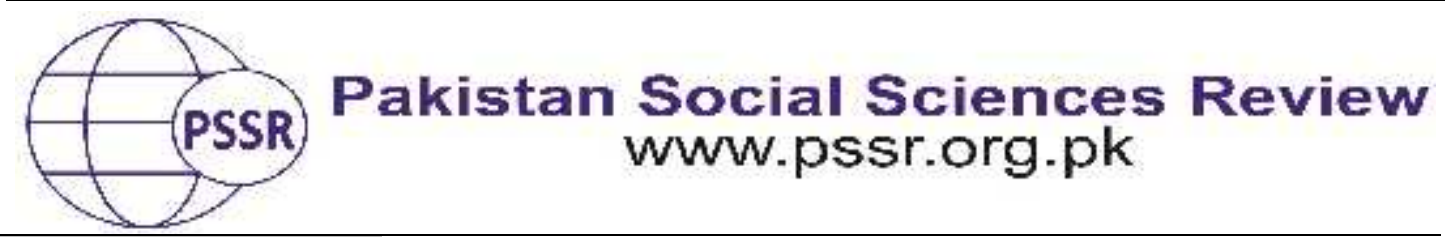

RESEARCH PAPER

\title{
Overall Impact of Action Research Project as Perceived By Pupil Teachers and Resource Persons of Allama Iqbal Open University, Islamabad
}

\author{
Dr. Mohammad Latif ${ }^{1}$ Dr. Razia Anjum ${ }^{2}$ Dr. Mubashir Hanif ${ }^{3}$
}

1. Assistant Professor, Incharge Department of Education, GC Women University Sialkot, Punjab, Pakistan

2. Lecturer, Department of Psychology, GC Women University Sialkot, Punjab, Pakistan

3. Deputy Director Research, Association of Academic Quality (AFAQ),Islamabad, Pakistan

\begin{tabular}{|c|c|}
\hline PAPER INFO & ABSTRACT \\
\hline $\begin{array}{l}\text { Received: } \\
\text { March 08, } 2021 \\
\text { Accepted: } \\
\text { July 01, } 2021 \\
\text { Online: } \\
\text { July 20, } 2021\end{array}$ & $\begin{array}{l}\text { Currently, AIOU Islamabad has made an action research project } \\
\text { compulsory for the students enrolled in these programs. They } \\
\text { are asked to select a topic of their own interest and carry out an } \\
\text { action research project. To study the impact of action research in } \\
\text { terms of improvement in the teaching practice of these beginner }\end{array}$ \\
\hline $\begin{array}{l}\text { Keywords: } \\
\text { Action Research, } \\
\text { Pupil Teachers, } \\
\text { Teaching Practice }\end{array}$ & $\begin{array}{l}\text { researchers who are called pupil teachers in this study. Inis } \\
\text { teachers who were available at Govt. high School No. } 2 \text { Kohat } \\
\text { during their workshop that was held from } 1^{\text {st }} \text { January, } 2020 \text { to }\end{array}$ \\
\hline $\begin{array}{l}\text { *Corresponding } \\
\text { Author }\end{array}$ & $\begin{array}{l}\text { 30th March, 2020. Thus a sample of } 150 \text { pupil teachers was } \\
\text { selected through convenient sampling on the basis of easily } \\
\text { availability. } 10 \text { Resource persons were interviewed and their } \\
\text { responses were noted down about their observation of the } \\
\text { learning experiences of their students (pupil teachers).A } 20 \\
\text { items questionnaire was used for collecting data from the pupil } \\
\text { teachers. The responses of } 10 \text { resource persons were noted } \\
\text { down by conducting a semi-structured interview. The study } \\
\text { revealed that the action research project had major impact on } \\
\text { the pupil teachers' research skills and communication skills. } \\
\text { The action research is recommended to be incorporated in } \\
\text { teaching at every level especially at university level. }\end{array}$ \\
\hline
\end{tabular}

\section{Introduction}

Allama Iqbal Open University, Islamabad is playing a vital role promoting education through its programs of distance learning. Especially, the programs of Teacher Education are very popular among students and a large number of students are enrolled in Programs i.e., B.Ed. (1.5\&B.Ed2.5years),M.Ed. M. Phil Education and Ph.D Education with different areas of specialization. Currently, Workshops of 
B.Ed1.5 and 2.5years programs at their centres, arranged by the respective regional centres of Allama Iqbal Open University, Islamabad. In the last few semesters, the pupil teachers were asked to complete their research project/thesis as well along with a teaching practice of one month in any school. Both the activities were carried out by the pupil teachers separately as requirements of their degree programs. In this semester, the pupil teachers have been asked to conduct action research and complete their one month's teaching practice in a school of their choice. An emphasis has been given on conducting a specific type of research (Action research) which is generally conducted by a practitioner for the sake of improving his/her own practice. In this case, the pupil teachers are expected to make their teaching practice better through conducting action research during their teaching practice of one month. Masoud, (2018) studied the perceptions of ESL teachers about the relationship between their research activities and teaching practice. It was considered appropriate to replicate the study in Pakistani context on the population of students enrolled in teacher education programs like B.Ed1.5 and 2.5 years of Allama Iqbal Open University, Islamabad to see the impact of ongoing action research project on their teaching practice.

This study was conducted to see the impact of the action research project on the teaching practice of the pupil teachers who were doing B.Ed. 1.5 year from AIOU in 2020. They were carrying out this project as a requirement of their degree program. So, they had to select a problem relevant to their teaching experience and were supposed to improve their deficiencies by conducting this project. This study was carried out to check the improvements in their teaching practice as a result of being involved in various activities of the action research project.

\section{Literature Review}

Kappalumakkel,(2018) reflective practice and action research are part and parcel. Hine,(2013)emphasizes on incorporating action research in teaching. Mills, (2011) considers Action research is an equally important option for all the stakeholders of education. According to Norton, (2009) action research is conducted for improving one's own practice. According to Kolk, (2018) teachers conduct action research for the sake of improving their own understanding and teaching practice. Teachers come to know about the problems in classroom teaching and their solutions as well. Edwards and Burns (2016) concluded that the action research program has a long term impact on their research activities. Atay (2008) concluded that action research programs are useful for the professional development of teachers. Borg and Alshumaimeri (2012) found that the teachers having higher qualifications and experience are more likely to be engaged in research activities than those who are less qualified and with little experience. Saggu (2016) stated that teachers must conduct action research to solve the problems of classroom teaching. Moreover he added that teachers can improve their own practice in local contexts through conducting action research. 
The study was delimited to the students enrolled in B.Ed. (1.5 and 2.5 years) programs of AIOU Islamabad who were available at Govt. High School for boys No.4 in the jurisdiction of Regional Director AIOU Kohat, Khyber Pakhtunkhwa.

The findings of this study have been drawn from the responses of Pupil teachers enrolled in B.Ed. (1.5 and 2.5 years) on a semi structured interview. Allama Iqbal open university, Islamabad is also offering some other programs of teacher education like M.Phil and Ph.D Education and the students enrolled in these programs are called "pupil teachers" but in this study, we depended on the responses of the pupil teachers enrolled in only B.Ed. 1.5 and 2.5 years programs because they were participating in workshop at Govt. Boys High school No:4, Kohat. So, the pupil teachers of other programs were excluded from the study.

\section{Null Hypotheses}

H0: There is no significant relationship between the action research project and teaching practice of pupil teachers.

H1: There is significant relationship between the action research project and teaching practice of pupil teachers.

\section{Material and Methods}

\section{Population}

Population of this study comprised of all the students of Allama Iqbal Open University, Islamabad enrolled in teacher education programs of B.Ed1.5 and 2.5years during the year2020.

\section{Sample}

A sample of 150pupil teachers enrolled in B.Ed1.5 and 2.5years programs were selected for this study that were available at Govt. High school No.4 that was a center of AIOU in Kohat region.

\section{Instrumentation}

A questionnaire was borrowed with the written permission of the concerned researcher and a modified version was prepared to be used in Pakistani context. It was a 20 items questionnaire. It consisted of 19 closed ended along with 1 open ended items. A semi-structured interview for the resource persons of Allama Iqbal Open University, Islamabad was also prepared and used for data collection. 


\section{Data Collection}

Data was collected by the researcher in person, using a questionnaire from pupil teachers. A semi-structured interview of the resource persons of Allama Iqbal Open University, Islamabad was conducted.

\section{Data Analysis}

The thematic analysis was done for the analysis of qualitative data collected from the resource persons of Allama Iqbal Open University, Islamabad and t-test was applied to compare the differences of mean scores of male and female pupil teachers.

\section{Results and Discussion}

\section{Resource Persons' Perspective}

The views of the resource persons who were engaged in teaching and research supervision of the action research projects of students of B.Ed. program of AIOU Islamabad were divided into the following themes:

- Students learnt practical research.

- They got awareness about "Soft Skills"

- Communication skills were improved.

- Critical thinking of the students was developed who participated in action research.

- Inter-personal skills were improved.

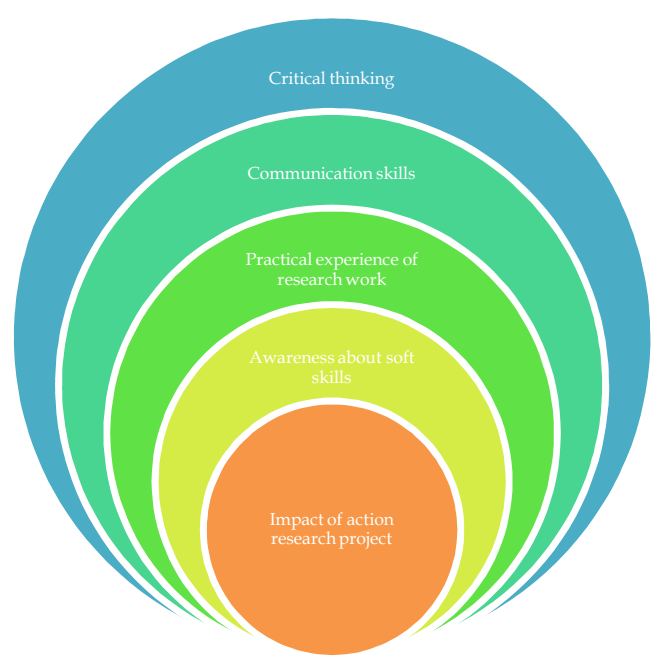


Impact of action research project as perceived by the resource persons of AIOU, Islamabad

A semi-structured interview of the resource persons was conducted who were involved in teaching and supervising the action research projects to the pupil teachers of AIOU Islamabad. The purpose of this interview was to get the perspective of the resource persons about the overall impact of action research project on teaching practice of the pupil teachers. By thematic analysis of the qualitative data, following themes were identified and summarized in the following table

Table 1

Thematic analysis of the qualitative data

\begin{tabular}{cc}
\hline Themes & Mentions \\
\hline Improved Communication skills & $32 \%$ \\
\hline Improved inter-personal social skills & $8 \%$ \\
\hline Improved critical thinking & $6 \%$ \\
\hline Improved Soft Skills & $3 \%$ \\
\hline Practical research kills & $36 \%$ \\
\hline Improved Teaching skills & $10 \%$ \\
\hline Improved problem solving & $2 \%$ \\
\hline
\end{tabular}

The table 1 reveals that $32 \%$ of the resource persons were convinced about the fact that the action research project has improved the communication skills of the pupil teachers whereas $36 \%$ of them believe that the pupil teachers have developed practical research skills that include ability to identify a research problem, develop and use a research instrument, collection and analysis of data and writing a research report skilfully.

Table 2

Impact of Action Research Project on research competencies of students of B.Ed

\begin{tabular}{|c|c|c|c|c|c|c|}
\hline$\underset{\sim}{*}$ & $\begin{array}{l}\overrightarrow{\overrightarrow{0}} \\
\overrightarrow{0} \\
\vec{\omega}\end{array}$ & 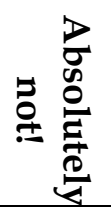 & 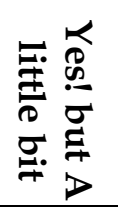 & 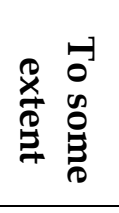 & 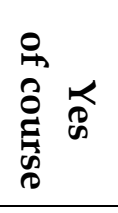 & 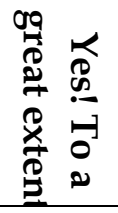 \\
\hline 1 & I can identify a research problem. & $2 \%$ & $20 \%$ & $20 \%$ & $38 \%$ & $40 \%$ \\
\hline 2 & I can develop research questions. & $3 \%$ & $10 \%$ & $40 \%$ & $41 \%$ & $7 \%$ \\
\hline 3 & $\begin{array}{l}\text { I can write a focused literature } \\
\text { review. }\end{array}$ & $6 \%$ & $9.2 \%$ & $19.8 \%$ & $42.9 \%$ & $22.1 \%$ \\
\hline 4 & $\begin{array}{l}\text { I can select an appropriate research } \\
\text { method for conducting a study. }\end{array}$ & $4.5 \%$ & $5.5 \%$ & $32.4 \%$ & $36.6 \%$ & $21 \%$ \\
\hline 5 & $\begin{array}{l}\text { I can justify a research method that } \\
\text { I choose for conducting a study. }\end{array}$ & $1.3 \%$ & $1.7 \%$ & $28.5 \%$ & $47.5 \%$ & $21 \%$ \\
\hline 6 & $\begin{array}{l}\text { I can develop a research } \\
\text { instrument. }\end{array}$ & $3.4 \%$ & $6.6 \%$ & $29.1 \%$ & $35.9 \%$ & $25 \%$ \\
\hline
\end{tabular}




\begin{tabular}{lllcccc}
\hline 7 & $\begin{array}{l}\text { I can collect data by using a } \\
\text { research instrument. }\end{array}$ & $4.1 \%$ & $5.9 \%$ & $23.7 \%$ & $35.3 \%$ & $31 \%$ \\
\hline 8 & I can analyze the quantitative data. & $0.3 \%$ & $1.7 \%$ & $34 \%$ & $42.5 \%$ & $21.5 \%$ \\
\hline 9 & I can analyze the qualitative data. & $2.9 \%$ & $10.1 \%$ & $44.1 \%$ & $20.9 \%$ & $22 \%$ \\
\hline 10 & I can practice research ethics. & $1.3 \%$ & $9.4 \%$ & $24.4 \%$ & $45.6 \%$ & $19.3 \%$ \\
\hline 11 & I can write a research report. & $17.2 \%$ & $25.8 \%$ & $31 \%$ & $14.6 \%$ & $11.4 \%$ \\
\hline 12 & $\begin{array}{l}\text { My research is a contribution for } \\
\text { knowledge. }\end{array}$ & $0 \%$ & $28 \%$ & $34 \%$ & $21 \%$ & $17 \%$ \\
\hline 13 & $\begin{array}{l}\text { My research is helpful in } \\
\text { improving practice. }\end{array}$ & $3 \%$ & $18 \%$ & $24 \%$ & $29 \%$ & $26 \%$ \\
\hline 14 & $\begin{array}{l}\text { My research project has improved } \\
\text { my teaching. }\end{array}$ & $2.7 \%$ & $18.3 \%$ & $29 \%$ & $23 \%$ & $27 \%$ \\
\hline 15 & $\begin{array}{l}\text { My research project has improved } \\
\text { my self-confidence. }\end{array}$ & $1 \%$ & $19 \%$ & $24 \%$ & $25.7 \%$ & $30.3 \%$ \\
\hline
\end{tabular}

Table 2 reveals that the experience of conducting an action research project has enabled the vast majority $(78 \%)$ of the pupil teachers of AIOU, Islamabad to identify a research problem, $87 \%$ can develop research questions, $65 \%$ can write a focused literature review, $57 \%$ can select a suitable research method for a particular research topic, $60 \%$ can develop a research instrument by their own, $66 \%$ can be engaged in data collection exercise, more than $60 \%$ can analyse the quantitative and qualitative data, $65 \%$ can practice research ethics intentionally. Though, a majority of the pupil teachers cannot write a research report skilfully yet a number of pupil teachers still not convinced about the impact of their own research work but they think that their action research project has improved their teaching practice in anyway and it has also improved their self-confidence as a teacher.

Table 3

Impact of Action Research Project on research competencies of students of B.Ed.(1.5)

\begin{tabular}{ccccccc}
\hline 16 & $\begin{array}{c}\text { My research project has changed the way I } \\
\text { work with my colleagues. }\end{array}$ & $3 \%$ & $8 \%$ & $33 \%$ & $35 \%$ & $21 \%$ \\
\hline 17 & $\begin{array}{c}\text { After conducting an action research project, } \\
\text { now I can better understand my students. }\end{array}$ & $4 \%$ & $13 \%$ & $36 \%$ & $32 \%$ & $15 \%$ \\
\hline 18 & $\begin{array}{c}\text { My research project was useful for my } \\
\text { students. }\end{array}$ & $3.9 \%$ & $9.1 \%$ & $19.6 \%$ & $36.4 \%$ & $31 \%$ \\
\hline 19 & $\begin{array}{c}\text { My teaching practice has improved after } \\
\text { taking an action research project. }\end{array}$ & $2.9 \%$ & $4.1 \%$ & $21.3 \%$ & $41.7 \%$ & $30 \%$ \\
\hline
\end{tabular}

It is obvious from table 3 that being engaged in action research project had a deep impact on the inter-personal behaviours of the pupil teachers. Now, they can understand their students better than they used to do before their research project. More than $67 \%$ of them believe that their action research project proved to be useful for their students in anyway and their teaching practice has been improved by passing through the experience of their research project. 
Table 4

Comparison of perceptions of male and female pupil teachers about the impact of Action research project

\begin{tabular}{ccccccccc}
\hline Group & $\mathrm{N}$ & Mean & S.D & df & $\alpha$ & tabulated & Calculated & \\
\hline $\begin{array}{c}\text { Male pupil } \\
\text { teachers of } \\
\text { AIOU }\end{array}$ & 70 & 2.6 & 1.29 & & & & & \\
\hline $\begin{array}{c}\text { Female pupil } \\
\text { teachers of } \\
\text { AIOU }\end{array}$ & 76 & 2.66 & 1.6 & & & & & \\
\hline
\end{tabular}

The table 4 manifests that the $p=0.42>0.05$ therefore there is no significant difference between the two groups. Therefore we accept $\mathrm{H}_{0}$ and conclude that there was no significant difference between the mean scores of two groups.

\section{Conclusion}

It was concluded that the Action research project had a significant impact on the teaching practice of the Pupil teachers. The most significant impact was noted in terms of improvement of practical research skills and communication skills of the pupil teachers. The results of this study are in line with the findings and conclusions of the study conducted by Masoud Rahimi in 2018 in Iranian Context. Masoud conducted his study on English language teachers in Iran whereas this study was conducted in Pakistani context on the pupil teachers enrolled in teacher education programs of Allama Iqbal Open University, Islamabad.

\section{Recommendations}

- It is recommended that the action research may be incorporated in teaching practice at primary school level in Pakistan.

- It is recommended that the action research may be incorporated in teaching practice at Secondary school level in Pakistan.

- It is recommended that the action research may be incorporated in teaching practice at College level in Pakistan.

- It is recommended that the action research may be incorporated in teaching practice at University level in Pakistan.

- It is recommended that the action research may be incorporated in teaching practice of Teacher Education level in Pakistan. 


\section{References}

Atay, D. (2008). Teacher research for professional development.ELT Journal, 62(2), 139-147.doi:10.1093/elt/ccl053

Borg, S., \& Alshumaimeri, Y. (2012). University teacher educators' research engagement: Perspectives fromSaudi Arabia. Teaching and Teacher Education, 28(3),347-356. doi:10.1016/j.tate.2011.10.011

Edwards, E., \& Burns, A. (2016). Language teacher action research: Achieving sustainability. ELT Journal, 70(1),6-15. doi:10.1093/elt/ccv060

Hine, Gregory. (2013). The Importance of Action Research in Teacher Education Programs. Issues in Educational Research. 23. 151-163.

Kappalumakkel, Thomas. (2018). Teacher As Reflective Practitioner Efl Classrooms.

Kolk, M. (2018). Embrace Action Research. https://www.thecreativeeducator.com/v07/articles/Embracing_Action_Resear ch

Masoud Rahimi \& Hiwa Weisi (2018). The impact of research practice on professional Teaching practice: Exploring EFL teachers' perception, Cogent Education, 5:1, 1480340

Mills, G.E. (2011). Action research: A guide for the teacher researcher (4th ed.). Boston: Pearson

Norton, L. (2019). Action Research in Teaching and Learning. London: Routledge, https://doi.org/10.4324/9781315147581

Saggu S., (2016). Action research related to Classroom problems. https://www.slideshare.net/sumansaggu/action-research-related-to-classroomproblems 